熱帯環境，とくにマングローブ沼の調査

$$
\text { （フランス領ニューカレドニア島） }
$$

系魚川淳二*・津田 禾粒** $・$ 山野井 徹***

\title{
Research Report on Tropical Environment, Especially on Mangrove Swamps in New Caledonia, Southern Pacific
}

Junji ITOIgAwA, Karyu TsudA and Tōru YAmANor

本調查は1980年以来行っている東南アジア地域 における，マングローブ沼の貝類群集および植物 花粉組成の調查の一環として行われたものであ る。

近年, 新潟県以西の各地において, 中新統中部 より, 熱帯的古環境を指示する各種化石が産し, 1500万年前頃, 日本列島が現在より温暖な熱帯〜 亜熱帯の状況にあったことが推定されている。当 時の古環境をより適確に復元するためには，現在 の状況との比較古環境学的研究が必要であり, そ の基礎的資料をうるために，これらの一連の現生 生物調查が計画され，実施された。

ニューカレドニア島は南半球に位置し, 緯度的 には台湾南部に対応する。赤道付近の東南アジア 各地や北半球の沖繩などの状況と比較するために は最適の地理的条件下にあり, サンゴ礁がよく発 達するにもかかわらず，適当な規模のマングロー ブ沼の存在が確かめられたので, 本調查を計画し た。

調查は1983年 6 月22日 29日の間, 主としてニ ユーカレドニア島南東部の, Numea, Dumbea, Tomo 地域で行われた。糸魚川・津田が貝類・堆 積など, 山野井が花粉を担当し, 探検家佐伯富男 が写真・記録などの面で調査をサポートした。以 下, 調査結果の概要, 今までの調査との関連, 日 本の中新世の熱帯的環境の問題点について述べ る。

1. ニューカレドニア島のマングローブ沼貝類
群集について。

二枚貝類 16 種, 腹足類 14 種, 計 30 種を同定し た。主要構成種として, Saccostrea mordax オ ハグロガキ, Geloina erosa ヤエヤマヒルギシジ ミ, Nerita Squamulata マルアマオブネガイ?, Littoraria scabra ウズラタマキビ, Terebralia palustris キバウミニナ, Clypeomorus patulum ミッカドカニモリ，C. humilis カヤノミカニモ リ, Cassidula nucleus カタシイノミミミガイな どがあげられる。

2. いわゆるマングローブ沼の環境にも変化が あることが判明した。普通考えられている河口の 汽水性環境でなく, normal salinity の地域にも マングローブ林植物のヒルギ類が分布し，独特な 貝類群集が見られる。

たとえば, Numea 東北の Tima 湾では, 海側 より山側に向って, 次のような生態的遷移が見ら れる。

石灰藻リーフ——ア “アマ”带（コゲッノブエ がすむ）—ーオヒルギ帯（樹上にウズラタマキ ビ，根上にミッカドカニモリ・マルアマオブネガ イ?, 泥底上にキバウミニナ)——芝地——地衣 類帯——“アッケシソウ”帯—ホウガンヒルギ 帯（カタシイノミミミガイがすむ）

3. 群集の種構成について, 東南アジア各地と 比較すると, Ritena Lineata（イトマキアマガ イ）が欠けて Nerita squamulata?（マルアマオ ブネガイ?）が分布する, Cerithidea, Cerithi-

* 名古屋大学理学部地球科学教室 Department of Earth Sciences, Nagoya University

** 新潟大学教養部地学教室 Faculty of General Education, Niigata University

*** 山形大学教養部地学教室 Faculty of General Education, Yamagata University 
deopsilla, Telescopium が欠け, Terebralia palustris（キバウミニナ）が存在する, Chicoreus capuchinus（クリイロバショウガイ）が欠ける, オカミミガイ科では他地域と異なって Cassidula nucleus（カタシイノミミミガイ）が代表する，と いった違いが見られる。

4. Terebralia palustris は赤道周辺地域の Telescopium の生態的地位を, 緯度 $20^{\circ}$ 以上の地 域で占めるものと推定される。沖繩において, 現 在, Telescopium の生殼が発見されないが（死殼 は見られる)，Terebralia palustris が分布する ことも，これと同様な理由によるものと思われ る。

東南アジア各地（ジャワ, バリ島, シンガポー ル，マレーシヤなど）の資料も総合すると，マン グローブ沼要素として, 次の属種があげられよ う。

Isognomon ephippium (マクガイ), Enigmonia aenigmatica (オカナミマガシワ), Crassostrea (マガキ) 属, Saccostrea mordax（オハグ ロガキ), Pretostrea affinis (コガネガキ), Geloina erosa (ヤエヤマヒルギシジミ), Anodonta corrugata (シワッキガイ), Ritena spp. (イトマ キアマガイ類), Nerita spp. (アマオブネガイ
類), Pila spp., Littoraria spp.（ウズラタマキ ビガイ類), Cerithidea spp. (オオヘナタリ類), Cerithideopsilla spp. (ヘナタリ類), Terebralia spp. (キバウミニナ類), Chicoreus capuchinus (クリイロバショウガイ), Cuma gradata (カス リレイシ), Ellobiidae (オカミミガイ科)の各種。 1950年の大山 桂による, 八尾層群黒瀬谷累層 からの Geloina, Telescopium の発見以来, 日本 の中新統中部からは，多くのマングローブ沼要素 の貝類化石が発見されている。現在までの知識を まとめると, 中新世のマングローブ沼要素の貝類 は第 1 表のようになる。これらは TelescopiumGeloina 群集としてまとめられる。

これと密接に関連して産するものに，いわゆる Vicarya-Anadara 群集がある。マングローブ沼 の外側の, やや深い, やや塩分濃度の高い地帯の 環境を示すものであろう。この他, マングローブ 沼要素でない，熱帯性種として，Perna oyamai, Maoricardium mizunamiensis, Tellinella osafunei, Turbo minoensis, Globularia nakamurai, Rimella toyamaensis, Volema osawanoensis などがあげられる。主に砂質底生息者である。

花粉化石について見ると, 黒瀬谷累層や備北層 群から，マングローブ林植物である，Bruguiera

第 1 表

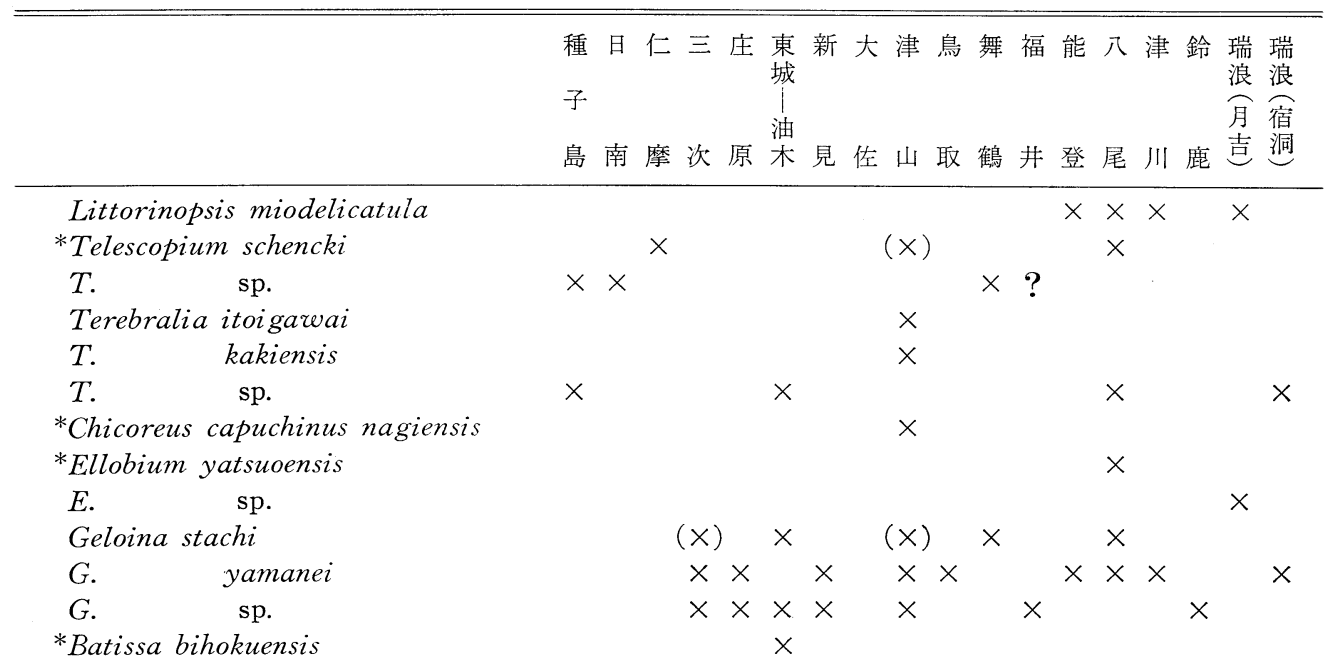

（）は cfr.のもの;* はとくに熱帯禾 
（オヒルギ）の花粉が発見され，さらに，山野井 は 7 種のマングローブ林植物の花粉の存在を確認 している。

Telescopium-Geloina 群集, これらの花粉化石 の分布から 推定すると, 中新世中期の中部日本 は，現在の沖繩南部あるいはそれ以南の環境条件
下にあったといえる。

新潟県下で発見された古赤色士, 各地の造礁性 サンゴ化石, アオウミガメ類の化石 (山口県産) もこれらの推定を裏付ける資料である。

本調查にあたって，援助を頂いた富山市の横田 力博士，東京地学協会に深く感謝する。 